\title{
What is a Responsible Supply Chain?
}

\author{
Terje I.Vaaland (Corresponding author) \\ UiS Business School, University of Stavanger \\ NO-4035 Stavanger, Norway \\ Tel: 47-9098-1256 E-mail: terje.vaaland@uis.no \\ Richard Afriyie Owusu \\ Faculty of Business Studies, University of Vaasa \\ FI-65101 Vaasa, Finland \\ E-mail: kwakus2403@hotmail.com
}

$\begin{array}{ll}\text { Received: October 24, } 2011 & \text { Accepted: November 9, } 2011 \quad \text { Published: February 16, } 2012 \\ \text { doi:10.5539/ijbm.v7n4p154 } & \text { URL: http://dx.doi.org/10.5539/ijbm.v7n4p154 }\end{array}$

The research is financed by A/S Norske Shell and the EPCI Foundation

\begin{abstract}
The paper introduces the concept of responsible supply chain based on two dimensions, the core processes of a supply chain and the concept of corporate social responsibility (CSR). It is suggested that a responsible supply chain is achieved through manifested core values of the supply chain actors, strategies, and tactics. The paper further discusses the individual supply chain actors' responsibility in securing a responsible supply chain beyond the actors' direct control. A conceptual model and a definition of a responsible supply chain are offered. Our model not only provides structure to the extant research but also develops new constructs and relationships that improve the conceptualization of the responsible supply chain. The paper is based on a review of 81 research articles published between 2000 and 2010 in which elements of CSR and supply chain processes are included.
\end{abstract}

Keywords: Corporate social responsibility, Ethics, Global sourcing, Strategy, Supply chain management

\section{Introduction}

Increasing competition is pushing multinational enterprises (MNEs) in the developed countries to outsource to countries with lower labor costs (Lim \& Phillips, 2007). In this strategy, companies try to produce a cheaper final product and improve their competitiveness by sub-contracting part or all of their production to producers in countries with lower labor costs. Thus, supply chains are becoming increasingly global and complex. Companies and governments in countries with lower labor costs in Eastern Europe, Asia, Latin America and Africa are increasingly dependent on this globalization in order to sustain economic growth. This trend has become an important driver of corporate strategies that has the potential to benefit all sides. Almost concurrently, corporate social responsibility (CSR) and related concepts like business ethics have been brought to the fore by non-governmental organizations, governments, and multilateral institutions partly as a result of the concern about limiting the negative effects of companies on society and the environment. For example the United Nations has established the "Global Compact", which is a set of principles aimed at achieving CSR (UN, 2011). As Smith (2007) argues in the case of Nike, the scale of production leads to the use of a large number of suppliers spread in countries whose policies Nike cannot control. However, in spite of the company initially claiming that it could not be expected to influence the CSR practices of its suppliers, it later was forced to act, leading to the establishment of internal values, strategies, and code of conduct with suppliers to ensure responsibility. The case of Nike exemplifies the ongoing challenges facing MNEs that are increasingly globalizing their supply chains to meet the changing competition as well as to enter growing emerging markets (Lim \& Phillips, 2008).

The responsible supply chain can be approached from two sets of literature - the CSR and the SCM literature. The CSR literature deals with a variety of responsibility issues and can be divided into three streams. One stream 
of CSR literature hold an intra-organizational focus on responsibility, for example, morality among purchasing executives (Ford et al., 2000). Another stream deals with responsibility within a business-to-business context, for example, illicit payments in buyer-seller relations (Millington et al., 2005), whereas a third stream focus on external stakeholder relationship, for example, the impact of code of conducts on labor standards (Yu, 2008). The SCM literature focuses on activities and decisions to enforce the competitiveness among supply chain partners. Some of these relate to selection of business partners in the supply chain (e.g. Vaaland \& Heide, 2005), others focus on the relational aspects of the interaction in the chain (e.g. Maignan et al., 2002; Worthington et al., 2008), and a third stream focuses on monitoring and follow-up of the performance in the chain and among partners in the chain (e.g. Gonzales-Padron et al., 2008). In spite of the growing inter-relationships between SCM and CSR, research and models that integrate them are limited (Pedersen, 2009; Ciliberti et al., 2008a). But there are some exceptions where CSR is studied in a supply chain context (e.g. Amaeshi et al., 2008; Ciliberti et al., 2008; Faisal, 2010). This article seeks to contribute in this line of research.

This paper seeks to provide a conceptual fundament for a responsible supply chain in which the supply chain is influenced by corporate social responsibility rather than a pure shareholder responsibility. It is suggested that a conventional supply chain can be made responsible by changing the frame of reference from a focus on shareholders to a focus on a broader set of stakeholders. The change in the frame of references is illustrated in the following:

\section{Insert Figure 1-here}

More specifically, the aim of this paper is to systemize current research from the last decade and propose a framework for understanding the dimensions of responsibility in a supply chain. The framework explores the pertinent question: what values, strategies, tactics and tools should companies and supply chains possess and implement in order to achieve a responsible supply chain? The framework is operationalized by exploring the question: to what extent should its implementation reflect differences across company size and complexity? Hence, is a responsible supply chain different for a large and complex MNE compared to a small and medium sized enterprise (SME) when it comes to values, strategies, tools and activities? These questions have been suggested as relevant by researchers such as Pedersen (2009) who studied the characteristics that determine the CSR behavior of SMEs in the supply chain. As Pedersen (2009) argues, the study of CSR has very much concentrated on MNEs and there is the need to consider the SME perspective. The rest of the paper is organized in five sections. In the following section the concept of SCM and CSR are briefly defined, then the method of selecting and analyzing articles are described. The following literature review is organized into three levels. The fourth section includes a conceptual framework followed by concluding remarks.

\section{Two Key Constructs}

Supply chain management (SCM) can be defined as "the management of all activities, information, knowledge and financial resources associated with the flow and transformation of goods and services up from the raw materials supplier, component suppliers and other suppliers in such a way that the expectations of the end users of the company are met or surpassed" (Van Weele, 2010, p.11). In this context a supply chain is considered as "...a series of companies (links) in which the consecutive stages of production of an economic product take place, from primary producer to final customer" (ibid: 411). The supply chain and its managerial challenges are tightly connected to the notion of global sourcing defined as ".proactively integrating and coordinating common items and materials, processes, design, technologies and suppliers across worldwide purchasing, engineering and operating locations "(ibid: 405). In this context the sourcing function has to be understood through an integrated view of interlinked activities, from primary producer to final customer. This view implies that the sourcing function affects activities to be carried out by suppliers and all levels of sub-suppliers further up the chain, and also "downstream" towards the end customer. In this perspective there is a significant risk that a problem created by wrong sourcing decisions or developing at another part of the chain will ripple through the chain and impact negatively on customers or other stakeholders in the society. Thus, supply chain management embraces three major activities or functions; (i) identifying, selecting and contracting supply chain actors, (ii) managing and developing the relationships in the chain, and (iii) monitoring and controlling performance of the actors.

Corporate Social Responsibility (CSR) has become a familiar phrase in management discourse that means different things to different people (Pettigrew, 2009). In the view of McWilliams et al. (2006), there are numerous definitions and dimensions of CSR and these are making theoretical development and measurement difficult. Dahlsrud's (2006) investigation of 37 definitions of CSR concluded, however, that various definitions are to a large degree congruent. We define CSR as the "management of stakeholder concern for responsible and irresponsible acts related to environmental, ethical and social phenomena in a way that creates corporate benefit" 
(Vaaland et al., 2008, p.929). Stakeholders are internal and external actors that impact the company and have an interest in its performance (ibid). In a supply chain context we argue that external stakeholders should be separated into those with which the focal company has a direct relationship (i.e. business-to-business interaction), and relationships between the focal company and stakeholders of the broader society (i.e. business-to-society interaction).

\section{Method}

The study includes a review of articles published in English in peer reviewed scientific journals. The article search was carried out within the ISI web database and included two sets of search criteria. One criterion pertains to supply chains and included the following items: suppliers, purchasing, supply chain, procurement, buying, vendor and contractor. The second includes criteria relating to corporate social responsibility, corporate citizenship, ethics, sustainability and codes of conduct. Articles including at least one item from each of the two groups in either the abstract, title or keywords of the article were included. The reason for applying two sets of search criteria is to limit the articles to those focusing on CSR in relation to the supply chain. In order to identify the most recent knowledge claims, the study includes only articles published between 2000 and 2010. A total of 106 articles were identified. After skimming the articles, 25 articles were excluded to end up with 81 articles; thus expelling articles with a general focus on CSR issues where suppliers/supply chain was only one out of several stakeholder groups. The study also excludes articles focusing on consumer and consumer behavior and/or with a primary focus on environmental issues. The selection criteria allowed an eclectic approach to articles, including a wide range of journals and different research streams. This was important since the phenomenon is an emerging field. The phenomenon of responsible supply chains has appeal to an audience beyond business and management scholars. The academic focus areas of the journals vary greatly from general marketing and management journals to journals representing other social sciences (e.g., the Journal of Contemporary Asia); political science (e.g., Human Rights Quarterly); geography (e.g. Geographical Research); ecology (e.g., World Ecology); and specific industries (e.g. British Food Journal ). Research on the globalization of the supply chain and CSR is quite new but has been growing fast. Therefore, we consider the time frame applied for selecting articles as adequate to encapsulate previous research as a basis for further conceptualization. The first step in the analysis was to identify the main findings and focus of the articles and arrange them into the two groups supply chain management (SCM) and corporate social responsibility (CSR). The authors scrutinized the articles individually and then cross-checked to reach consensus. The conceptual building blocks of the proposed framework emerged from the reviewed literature. A detailed list of journals and articles included in the literature base is provided in appendices.

\section{Literature Review}

The review of the articles revealed three areas in which supply chain issues were discussed in relation to CSR. The first group explored values regarding CSR. A second group discussed strategies, programs and approaches to sustain responsibility. The final group of articles dealt with the operational level and discussed specific and practical tools and activities on a tactical level. The following review of articles will therefore be organized under the headings of values, strategies, and tactics.

\subsection{Values}

Values reflect the world views of the organization and how it will behave. They determine the content of strategy and its acceptance (Liedtka, 2000), and typically comprise a set of organizational behaviors and key principles to which employees should subscribe (Thompson \& Martin, 2010). In other words values represent the underlying principles that guide an organization's strategy (Johnson et al., 2009). Corporate values are relevant both in terms of the acceptance of the various CSR elements and in terms of the way inter-organizational relationships are organized, developed, managed and followed up. They constitute the identity of a company and are manifested on several levels, ranging from a personal level (i.e. employees and managers), through a corporate level, to an inter-organizational and supply chain level in which the company is embedded. Individual values, i.e. the world views and value systems of individuals working in the company, interact with and impact organizational values (Ford et al., 2000; Fischer, 2007). For example, the values of managers can impact how they perceive the consequences of ethical/unethical buying decisions (Cole et al., 2000; Park, 2005). Values enable companies to decide between competing goals, for example, the extent to which shareholder values are more important than supply chain profitability, or social concerns in the community.

The corporate values of the individual supply chain members influence the type of relationship among them. Supply chain members can encourage the acceptance of value systems and powerful buyers are able to impose their responsible value systems on the rest of the chain (Lim \& Phillips, 2008; Smith, 2007; Gonzalez-Padron et 
al., 2008). Powerful buyers have a duty to create a climate that forces or encourages their suppliers to adhere to responsible practices (Amaeshi et al., 2007) and should take greater responsibility for achieving CSR (Hsueh \& Chang, 2008). Ethical and honest buyers are positively perceived and they encourage similar values among suppliers (Bendixen \& Abratt, 2007). Other studies are concerned about gift-giving and the use of incentives to sustain inter-organizational relationships (Fisher, 2007; Millington et al., 2005). The interaction between personal and corporate values impact how managers interpret and react to buying/sourcing decisions (Park, 2005). Even though the values of powerful buyers from developed countries are critical, those of the developing country suppliers in achieving CSR cannot be disregarded. The supplier in the developing country has the direct ability to improve its labour and environmental practices (Lim \& Phillips, 2008; Locke \& Romis, 2007; Mamic, 2005). Some studies address the relationship between corporate values and the performance of the supply chain. According to Lim \& Phillips (2008) and Ni et al. (2010), one of the challenges of developing an ethical supply chain is related to the distribution of benefits among the members of the chain. Hsueh \& Chang (2008) and Cruz \& Matsypura (2009) try to estimate the costs and profitability effect of CSR investments in the supply chain. Others investigate the supply chain effect of reduced ethical standards in the long run (e.g. Svensson \& Baath, 2008), and the effect of the development and communication of ethical norms on workforce stability and satisfaction (e.g. Baker et al., 2006).

Whereas the studies above focus on values within and between the supply chain members, another line of research addresses values and goals from stakeholders outside the focal supply chain influence. One group of studies addresses phenomena related to the role of government, legal frameworks and political institutions (e.g. Lawrence, 2007; Lillywhite, 2007; Barrientos, 2008; Aaronson, 2005). Governments, legal frameworks and political institutions are seen to provide the overarching institutional framework and rules of CSR. Another group addresses the role of NGO's, unions and international organizations when managing a supply chain, for example in securing fairness in labor practices and conditions among suppliers (e.g. Worthington et al., 2007). Whereas the majority of studies take the perspective of the Western company, others address specifically the value systems of the developing country authorities in imposing CSR in their own supplier industry (e.g. Tsoi, 2010). Some call for institutional reforms to deliver change towards more fairness in supply chain behavior (e.g. Studer et al., 2008). The studies by Smith (2009), and Locke \& Romis (2007) show how CSR standards have evolved and how the pressure from societal stakeholders have forced powerful buyers to develop and implement responsible values in their supply chains.

When summing up the studies focusing on values one can identify the connection between values and supply chain activities (e.g. buying decisions and partner selection) as well as the connection between values and various levels of responsibility (intra-organizational, business-to-business and business-to-society levels).

\subsection{Strategies}

Strategy can be described as the direction and scope of an organization over the long term, which enables it to achieve competitive advantage through its configuration of resources and competences with the aim of fulfilling stakeholder expectations (Johnson et al., 2009). Strategies are affected by and, they in turn affect the content of CSR in the company (e.g. ethics and business practices), as well as the choice and management of suppliers and other elements in the sourcing process.

The literature addressing supply chain strategies focus on three main issues. The first pertains to how collaboration between the actors in the chain takes place. More specifically how the relationships between the actors are developed and sustained, including the networking effect of collaboration. For example how the supplier performance can be enhanced through improved trust and cooperation (Carter \& Jennings, 2002), and how mutual relationships can overcome the barriers to CSR in the supply chain (Faisal, 2010). Other studies address the power of networking in developing countries as a counteracting force to domination from powerful global players (Pangsapa \& Smith, 2008). Several studies focus on networking between the global buyers, local suppliers and stakeholders in a developing country (e.g. Svensson \& Baath, 2008; Jiang, 2009) with the aim of ensuring CSR. Another aspect of strategy concerns buying practices and pricing. The issue of fair purchasing and pricing strategies by powerful buyers is studied by Fearne et al. (2005) who propose that fair purchasing and pricing strategies are best for all members of the chain. The nature of supply chain strategies, for example by establishing direct links from retailer to producers enables them to influence the suppliers in a positive or negative way (Hale \& Opondo, 2005). Rode et al. (2008) found that consumers were willing to pay a premium for ethical products and therefore ethical producers would recover higher costs of production. Welford et al., (2003) explored fair trade strategies and standards and how they could increase the competitiveness of companies and their supply chains. Other studies try to establish normative sourcing and purchasing strategies, stakeholder influence (Maignan et al., 2002; Maignan \& McAlister, 2003) and supplier diversity (Worthington et 
al., 2007). Some strategies are developed to provide responsibility in the link between a powerful buyer and weaker supplier, usually in a developing country, for example when Hale \& Opondo (2005) and Jiang (2009) address implications of strategies preventing the abuse of workers' rights and "irresponsible" hiring practices. A third aspect of strategy in the supply chain context relates to the organization of production, the danger of non-cooperative "power driven" market governance (Drake \& Schlachter, 2008; Locke \& Romis, 2007) and the importance of a holistic view of the supply chain (Ciliberti et al. 2008a; Petrovic-Lazarevic, 2008).

Some CSR phenomena addressed on strategic level can be related to an intra-organizational level, such as when Boyd et al. (2006) and Roberts (2003) discusses strategies for how the individual company can develop ethical sourcing or when Ciliberti et al. (2008b) discuss the company's logistics social responsibility. The boundaries are not very distinct, but some studies direct the attention from intra-organizational towards inter-organizational aspects of CSR. Examples include studies of ethical trade and fairness between the actors (e.g. Welford et al., 2003; Hughes, 2005; Maignan et al., 2002). Powerful buyers and MNEs from the rich countries are being increasingly impacted by the demands for CSR from various societal stakeholders. These actors include NGO's, multi-lateral organizations and local institutions and their activities address challenges on a business-to-society level (B2S). Examples of CSR issues on a B2S level include the problem of local suppliers who violate social and environmental norms in the local community (e.g. Pangsapa \& Smith, 2008) and strategies for how powerful global players can achieve higher ethical standards among suppliers in developing countries (Svensson \& Baath, 2008; Setthasakko; 2007). One way to achieve this is included in the case study by Lim and Phillips (2007), which show how external pressure forced Nike to gradually act and change a considerable part of its supply chain strategies in order to meet CSR.

Summing up on the strategic level, several supply chain strategies are addressed including collaboration between the actors, selection of suppliers and organization of production, and strategies related to securing supply chain performance. The literature in this category also addresses responsibility along three dimensions of CSR: intra-organizational, business-to-business, and business-to-society.

\subsection{Tactics}

Tactics are the specific activities which deliver and implement the strategies in order to meet objectives and pursue the mission. They are short term and can be changed frequently if necessary (Thompson \& Martin, 2010). Tactics are often manifested in short-term plans or programs which can be described as specific actions that follow from the strategies (Lynch 2009). Actions to sustain local community dialogue and monitoring supplier performance illustrate the connection between CSR and sourcing on the tactical level of a company and the supply chain.

One group of studies is related to the company's standard operating procedures targeted toward the supply chain and suppliers. These procedures are often specified in terms of codes of conduct. Aspects of codes of conduct include the purpose and practical function of codes (e.g. Bendixen \& Abratt, 2007; Mamic, 2005) and driving forces behind introduction of codes (e.g. Lim \& Phillips, 2007). Some articles address challenges in developing codes such as how to combine the collaborative sub-contracting systems that they imply with profit maximization and competition realities (Locke \& Romis, 2007; Yu, 2008). Others focus on implementation issues (Oehmen et al., 2010; Lillywhite, 2007) and the limitations of codes (e.g. Nadvi, 2008). A second group relates to the follow up of performance in terms of auditing and monitoring. Issues include challenges in monitoring performance (e.g. Egels-Zandén, 2007; Boyd et al., 2006), effects of monitoring and auditing (Nadvi, 2008; Locke et al., 2007) and how effective monitoring should be organized and developed (Christmann \& Taylor, 2006; Hughes, 2005). These studies represent tactical ways to secure a responsible supply chain from the perspective of the supply chain members. Other studies enter a broader B2S perspective and argue that stakeholders including governments, NGOs, consumer groups and civil society should push multinational companies to adhere to human and workers' rights (Lim \& Phillips, 2007; Worthington et al., 2007) and enter what Hale \& Opondo (2005a) label as a multi-stakeholder approach. Reporting and the mode of communicating CSR to society are also scrutinized in a B2S context (e.g. Tate et al., 2010).

Summing up on the tactical level we see at least two important supply chain issues; monitoring and controlling, and that CSR dimensions include aspects related to the individual company, the buyer-seller relationship, the supply chain and stakeholders from the broader society.

\section{Discussion}

The review of literature revealed that aspects of CSR are attached to a wide range of SCM issues. These issues are discussed on various levels, ranging from business values, to the strategies where the values are pursued and further into a tactical level where the strategies are operationalized. Albeit previous literature includes various 
elements of a responsible supply chain, a framework where CSR is conceptually attached to the SCM processes is needed. The suggested framework is based on two major assumptions which are extracted during the review process: Firstly, CSR can be related conceptually and empirically to at least three dimensions; intra-organizational, business-to-business (B2B) and business-to-society (B2S). Secondly, SCM consists of three overarching processes or dimensions. Partner selection is the process of identifying and contracting supply chain actors by business buyers and suppliers. Relationship development is the process of maintaining and developing relationships between buyers, suppliers and other supply chain actors through various marketing and management activities. Monitoring and controlling processes are undertaken among the supply chain actors to establish specifications and ensure standards and quality compliance. These three basic activities are related to internal considerations and to the relationship with the immediate business partners, but also to the whole supply chain.

On the way towards a framework for a responsible supply chain one pertinent question arises: Should all three dimensions of CSR, and all three SCM dimensions be included in order to define a responsible supply chain, and if so, how? The basic assumption is that a responsible supply chain should be manifested in terms of values, strategies and tactics. We argue that each of these should include CSR elements from all dimensions, ranging from issues within internal managerial control of the company, to how the interaction with other business partners are carried out, to how the supply chain partners relate to society and external stakeholders. Furthermore, we argue that no basic SCM activity should be left out, which means that partner selection, relationship development and follow-up should be included and connected with CSR. Following our arguments we define the responsible supply chain (RSC) as:

"A responsible supply chain is a link of business actors who jointly adopt, implement and coordinate values, strategies and tactics in order to connect all levels of corporate social responsibility to the business processes in the chain."

This definition reflects a collective (joint) responsibility to sustain a responsible supply chain. But the capabilities and resources, opportunities and power may vary significantly among the individual actors in a supply chain. Thus the impact on the level of RSC is determined, not only by attitudes and values, but the ability to implement and enforce these values. We therefore argue that the responsible supply chain does not necessarily require all actors in the chain to equally implement all three dimensions of CSR and SCM, even though the responsibility to do their best according to their resources and position in the chain remains.

In the following conceptual model, we propose a pattern of supply chain responsibility. This implies that there is a minimum threshold of "responsibility" for an actor in the supply chain. The threshold implies that any actor in the RSC has established CSR values internally as a minimum, and is able to avoid doing business with "irresponsible" actors in the chain. However, if all actors in the chain only are present at this threshold level, the RSC cannot be achieved. The RSC requires at least one actor with the capabilities to connect the three CSR dimensions with the supply chain dimensions through values, strategies and tactics. The following framework illustrates the two basic dimensions to be undertaken through values, strategies and tactics in order to achieve a RSC. The framework also suggests a relationship between the supply chain dimension and CSR dimension. The more supply chain activities are included, the more important it is to include the B2S dimension of CSR.

\section{Insert Figure 2-here}

In figure 2 the vertical axis illustrates the CSR dimension which could be manifested at intra-organizational level (as a minimum), added with a B2B level, and a B2S level. The horizontal axis displays the CSR dimension which includes the core processes to be connected to CSR. Values and strategies for a "responsible" partner selection is a minimum, but could be added with proactive development of inter-organizational relationships and activities related to securing manifestation of CSR through monitoring and controlling the chain.

We suggested that the supply chain members may have different capabilities available for securing responsibility in the chain. If so, what criteria are relevant for deciding the individual company's responsibility for the chain as a whole? One of these criteria could be the relative size, influence and power of the actor in the supply chain. The literature review gives some leads. Individual company characteristics will determine the nature of supply chain management practices (Pedersen, 2009; Ciliberti et al., 2008a) the nature of CSR demands, responsibility and associated reputational risk (Palazzo and Richter, 2005; Roberts, 2003); and the power and influence of the company in the supply chain (Lim \& Phillips, 2008; Amaeshi et al., 2007). Thus, the position along the "pattern of responsibility" depends on the size of company and the overall risk of sanctions when violating CSR standards in society. These variations will be illustrated through a complex MNE, assumed to have significant influence on the activities and behaviors in the chain, and a less complex and less influential SME (Pedersen, 
2009; Lim \& Phillips, 2008), in which both types of organizations work towards responsibility in the supply chain. This is in accordance with Pedersen (2009) who argues for the need for more differentiated initiatives to promote CSR that will enable smaller enterprises to address CSR in the supply chain. Laudal (2010), who studied larger enterprises, follows this line of thought by claiming that sector-specific features influence the "CSR potential", i.e. the risk of violating CSR standards. Based on the literature review, differences between the SME and the MNE are articulated in terms of CSR expectations on B2S level expectations as a conventional supply chain partner and as a responsible supply chain partner are illustrated in the following table.

\section{Insert Table 1-here}

Table 1shows that the SME should focus on "responsible" values beyond pure profit maximization and ensure that these values are manifested on individual and corporate level. Accordingly, responsibility is likely to have an internal focus, and to avoid collaborating with irresponsible business partners. There is a possibility to use CSR as a market opportunity, on certain niches, but CSR investments might in general be limited to passively adapt to the "leaders of the chain". For the SME to be responsible, corporate values need to reflect general responsibility, including implementing responsible strategies, and monitoring supplier's CSR performance. A careful partner selection to include "responsible" partners is emphasized. However, the SME should also apply external strategies when possible. The MNE, on the other hand, needs to extend the focus to the business relationships in the supply chain and towards the external stakeholders. CSR investment should follow clear strategies and be supported by tactical tools and activities along the chain. The MNE bears the major responsibility for an irresponsible supply chain, and has the resources to improve this. Any responsible company in a supply chain needs an intra-organizational CSR foundation, an understanding and manifestation of values, and a deliberate selection of right partners in the supply chain. The bigger and more powerful the company, the more of the dimensions needs to be included. The positions are illustrated in Figure 3.

\section{Insert Figure 3-here}

The MNE and the SME represent two extremes and many companies belong along a continuum between the extremes. Figure 3 reflects this continuum, in which a specific company should be positioned along the two dimensions and take the appropriate responsibilities. The larger and more influential the company, the more of the three dimensions should be included in corporate attention and action. The CSR dimension reflects to what extent the focus is limited to intra-organizational, business-to-business or business-to-society aspects of CSR. Whereas the SME might hold more of an internal focus, the MNE should include all three CSR levels. The pattern of supply chain responsibility relates to the extent to which the company might limit their concern to own business values, or include proactive strategies and tactics in order to secure and influence the supply chain. We argue that only the influential MNE should be expected to include all three. In the supply chain dimension the activities to pursue a responsible supply chain are, for a small SME, limited to partner selection. The task of developing relationships and monitoring \& following up other supply chain partners with the purpose of securing and improving the responsible supply chain should be a task for the MNE, to a much greater extent.

\section{Concluding remarks}

This study was based on research articles published between 2000 and 2010 within the area of supply chain management and corporate social responsibility. The selected articles included both areas, and were used as conceptual building blocks for a framework in which the constituents of a responsible supply chain (RSC) can be discussed and analyzed. We argued that a RSC implies that all major supply chain activities (i.e. business processes) are related to all levels of CSR. The supply chain activities include partner selection, relationship development and monitoring \& controlling which were included in the SCM dimension. CSR was divided into three levels embracing intra-organizational level, business-to-business level, and business-to-society level. This connection between SCM and CSR was possible through emphasis on values, strategies and tactical initiatives. Hence we proposed the following definition of "a responsible supply chain as a link of business actors who jointly adopt, implement and coordinate values, strategies and tactics in order to connect all levels of corporate social responsibility to the business processes in the chain".

The individual actors own contribution for achieving and maintaining the totality of a RSC depends on company characteristics. The difference between the small and less influential SME and the large and powerful MNE is to what extent these considerations are targeted to own organization, or also targeted beyond own corporate boundaries towards the behavior in the whole supply chain. We thus argue that a small retailer with very limited influence on the behavior of other actors in the chain, and thus the totality of responsibility in the chain, still can be considered responsible. As member of a responsible supply chain, however, the SME is expected to move beyond considering the three dimensions, to make possible changes within its own area of influence, at least 
within its own organization. A MNE or a more influential smaller company are violating the responsible supply chain if they in addition to scrutinizing the chain for irresponsibility, do not use their opportunity to make appropriate changes in business practices in the supply chain as a whole, beyond their corporate boundaries, since their influence is significant.

The achievement of a responsible supply chain is a challenge. The number of actors and complexity of interaction between actors in the chain is high, the competition and cost pressure hard, cultural differences in a global chain are difficult to handle, and an unlimited number of demanding stakeholders makes the responsible supply chain a dynamic and sometimes ambiguous mission. Nonetheless it is even more important to continue research for new methods and tools for integrating corporate social responsibility to supply chain activities.

\section{References}

Aaronson, S. A. (2005). Minding Our Business: What the United States Government has done and can do to ensure that U.S. Multinationals act responsibly in foreign markets. Journal of Business Ethics, 59, 175-198. http://dx.doi.org/10.1007/s10551-005-3414-z

Amaeshi, K. M., Osuji, O. K., \& Nnodim, P. (2008). Corporate social responsibility in supply chains of global brands: a boundaryless responsibility? Clarifications, exceptions and implications. Journal of Business Ethics, 81, 223-234. http://dx.doi.org/10.1007/s10551-007-9490-5

Armstrong, J. S. (1977). Social irresponsibility in management. Journal of Business Research, 5(3), 185-213. http://dx.doi.org/10.1016/0148-2963(77)90011-X

Baker, T. L., Hunt, T. G., \& Andrews, M. C. (2006). Promoting ethical behavior and organizational citizenship behaviors: the influence of corporate ethical values. Journal of Business Research, 59, 849-857. http://dx.doi.org/10.1016/j.jbusres.2006.02.004

Barrientos, S. (2008). Contract labour: the 'Achilles heel' of corporate codes in commercial value chains. Development and Change, 39(6), 977-990. http://dx.doi.org/10.1111/j.1467-7660.2008.00524.x

Bendixen, M., \& Abratt, R. (2007). Corporate identity, ethics and reputation in supplier-buyer relationships. Journal of Business Ethics, 76, 69-82. http://dx.doi.org/10.1007/s10551-006-9273-4

Besser, T. L., Miller, N., \& Perkins, R. K. (2006). For the greater good: business networks and business social responsibility to communities. Entrepreneurship \& Regional Development, 18(July), 321-339. http://dx.doi.org/10.1080/08985620600715046

Blowfield, M. (2000). Ethical sourcing: a contribution to sustainability or a diversion. Sustainable Development, 8, 191-200. http://dx.doi.org/10.1002/1099-1719(200011)8:4<191::AID-SD146>3.0.CO;2-E

Carter, C. R. (2000). Ethical issues in international buyer-seller relationships: a dyadic examination. Journal of Operations Management, 18, 191-208. http://dx.doi.org/10.1016/S0272-6963(99)00016-9

Carter, C. R., \& Jennings, M. M. (2002). Social responsibility and supply chain relationships. Transportation Research E, 38, 37-52. http://dx.doi.org/10.1016/S1366-5545(01)00008-4

Choi, T. H., \& Jung, J. (2007). Ethical commitment, financial performance, and valuation: an empirical investigation of Korean companies. Journal of Business Ethics, 81, 447-463. http://dx.doi.org/10.1007/s10551-007-9506-1

Christmann, P., \& Taylor, G. (2006). Firm self-regulation through international certifiable standards: determinants of symbolic versus substantive implementation. Journal of International Business Studies, 37, 863-878. http://dx.doi.org/10.1057/palgrave.jibs.8400231

Ciliberti, F., Pontrandolfo, P., \& Scozzi, B. (2008a). Investigating corporate social responsibility in supply chains: a SME perspective. Journal of Cleaner Production, 16, 1579-1588. http://dx.doi.org/10.1016/j.jclepro.2008.04.016

Ciliberti, F., Pontrandolfo, P., \& Scozzi, B. (2008b). Logistics social responsibility: standard adoption and practices in Italian companies. International Journal of Production Economics, 113, 88-106. http://dx.doi.org/10.1016/j.ijpe.2007.02.049

Cole, D., Sirgy, J. M., \& Bird, M. M. (2000). How do managers make teleological evaluations in ethical dilemmas? Testing part of and extending the Hunt-Vitell model. Journal of Business Ethics, 26, 259-269. http://dx.doi.org/10.1023/A:1006106300954

Craig Smith, N. (2009). Bounded goodness: marketing implications of Drucker on corporate responsibility. 
Journal of the Academy of Marketing Science, 37, 73-84. http://dx.doi.org/10.1007/s11747-008-0110-4

Cramer, J. M. (2008). Organising corporate social responsibility in international product chains. Journal of Cleaner Production, 16, 395-400. http://dx.doi.org/10.1016/j.jclepro.2007.01.007

Cruz, J. M. (2008). Dynamics of supply chain networks with corporate social responsibility through integrated environmental decision-making. European Journal of Operational Research, 184, 1005-1031. http://dx.doi.org/10.1016/j.ejor.2006.12.012

Cruz. J. M., \& Matsypura, D. (2009). Supply chain networks with corporate social responsibility through integrated environmental decision-making. International Journal of Production Research, 47(3), 621-648. http://dx.doi.org/10.1080/00207540701513901

Cruz, J. M., \& Wakolbinger, T. (2008). Multiperiod effects of corporate social responsibility on supply chain networks, transaction costs, emissions, and risk. International Journal of Production Economics, 116, 64-74. http://dx.doi.org/10.1016/j.ijpe.2008.07.011

den Butter, F. A. G., \& Linse, K. A. (2008). Rethinking procurement in the era of globalization. MIT Sloan Management Review, 50(1), 76-207.

Donaldson, T., \& Preston, I. (1998). The Stakeholder Theory of the Corporation: Concepts, Evidence, and Implications. Academy of Management Review, 20 (1), 65-91.

Drake, M. J., \& Schlacter, J. T. (2008). A virtue-ethics analysis of supply chain collaboration. Journal of Business Ethics, 82, 851-864. http://dx.doi.org/10.1007/s10551-007-9597-8

Dubbink, W., \& van der Putten, F. P. (2008).Is competition law an impediment to CSR? Journal of Business Ethics, 83, 381-395. http://dx.doi.org/10.1007/s10551-007-9626-7

Egels-Zandén, N. (2007). Suppliers' Compliance with MNCs' codes of conduct: behind the scenes at Chinese toy suppliers. Journal of Business Ethics, 75, 45-62. http://dx.doi.org/10.1007/s10551-006-9237-8

Emiliani, M. L. (2005). Regulating B2B online reverse auctions through voluntary codes of conduct. Industrial Marketing Management, 34, 526-534. http://dx.doi.org/10.1016/j.indmarman.2004.12.003

Faisal, M. N. (2010). Analysing the barriers to corporate social responsibility in supply chains: an interpretive structural modelling approach. Intl.J.of Logistics - Research and Applications, 13(3), 179-195.

Fearne, A., Duffy, R., \& Hornibrook, S. (2005). Justice in UK supermarket buyer-supplier relationships: an empirical analysis. International Journal of Retail \& Distribution Management, 33(8), 570-582. http://dx.doi.org/10.1108/09590550510608377

Fisher, J. (2007). Business marketing and the ethics of gift giving. Industrial Marketing Management, 36, 99-108. http://dx.doi.org/10.1016/j.indmarman.2005.03.013

Ford, J. B., LaTour, M. S., \& Henthorne, T. L. (2000). Cognitive Moral Development and Japanese procurement executives: implications for Industrial Marketers. Industrial Marketing Management, 29, 589-600. http://dx.doi.org/10.1016/S0019-8501(00)00119-X

Frederick, W. C. (1994). From CSR1 to CSR2: the maturing of business-and-society thought. Business and Society, 33(2), 150-164. http://dx.doi.org/10.1177/000765039403300202

Giampietro, C., \& Emiliani, M. L. (2007). Coercion and reverse auctions. Supply Chain Management: an International Journal, 12(2), 75-84. http://dx.doi.org/10.1108/13598540710737253

Gonzalez-Padron, T., Hult, T. G., Tomas, M., \& Calantone, R. (2008). Exploiting innovative opportunities in global purchasing: an assessment of ethical climate and relationship performance. Industrial Marketing Management, 37, 69-82. http://dx.doi.org/10.1016/j.indmarman.2007.06.013

Hadjikhani, A., \& Håkansson, H. (1996). Political actions in business networks: a Swedish case. International Journal of Research in Marketing, 13, 431-447. http://dx.doi.org/10.1016/S0167-8116(96)00024-9

Hale, A., \& Opondo, M. (2005). Humanising the cut flower chain: confronting the realities of flower production for workers in Kenya. Antipode, 301-323. http://dx.doi.org/10.1111/j.0066-4812.2005.00494.x

Hillman, A. J., \& Keim, G. D. (2001). Shareholder value, stakeholder management, and social issues: what's the $\begin{array}{lllll}\text { Bottom Line? } \quad \text { Strategic } & \text { Management }\end{array}$ http://dx.doi.org/10.1002/1097-0266(200101)22:2<125::AID-SMJ150>3.0.CO;2-H

Hsueh, C. F., \& Chang, M. S. (2008). Equilibrium analysis and corporate social responsibility for supply chain 
integration. European Journal of Operational Research, 190, 116-129. http://dx.doi.org/10.1016/j.ejor.2007.05.037

Hughes, A. (2005). Corporate strategy and the management of ethical trade: the case of the UK food and clothing retailers. Environment and Planning, 37, 1145-1163. http://dx.doi.org/10.1068/a3753

Hutchins, M. J., \& Sutherland, J. W. (2008). An exploration of measures of social sustainability and their application to supply chain decisions. Journal of Cleaner Production, 16, 1688-1698. http://dx.doi.org/10.1016/j.jclepro.2008.06.001

Johnson, G., Scholes, K., \& Whittington, R. (2009). Fundamentals of Strategy, London: Prentice Hall.

Keating, B., Quazi, A., Kriz, A., \& Coltman, T. (2008). In pursuit of a sustainable supply chain: insights from Westpac Banking Corporation. Supply Chain Management: An International Journal, 13(3), 175-179. http://dx.doi.org/10.1108/13598540810871217

Lahdesmaki, M. (2005). When ethics matters - interpreting the ethical discourse of small nature-based entrepreneurs. Journal of Business Ethics, 61, 55-68. http://dx.doi.org/10.1007/s10551-005-5333-4

Lantos, G. P. (2001). The boundaries of strategic corporate social responsibility. Journal of Consumer Marketing, 18(7), 595-630. http://dx.doi.org/10.1108/07363760110410281

Lantos, G. P. (2002). The ethicality of altruistic corporate social responsibility. Journal of Consumer Marketing, 19(3), 205-230. http://dx.doi.org/10.1108/07363760210426049

Laudal, T. (2010). An attempt to determine the CSR potential of the international clothing business. Journal of Business Ethics, 96(1), 63-77. http://dx.doi.org/10.1007/s10551-010-0449-6

Lawrence, R. (2007). Corporate social responsibility, supply-chains and Saami claims: tracing the political in the Finnish Forestry Industry. Geographical Research, 45(2), 167-176. http://dx.doi.org/10.1111/j.1745-5871.2007.00448.x

Liedtka, J. (2000). Strategy as design. California Management Review, 42(3).

Lillywhite, S. (2007). Ethical purchasing and worker's rights in China: The case of the Brotherhood of St.Laurence. Journal of Industrial Relations, 49(5), 684-700. http://dx.doi.org/10.1177/0022185607082216

Lim, S. J., \& Phillips, J. (2008). Embedding CSR Values: The Global Footwear Industry's Evolving Governance Structure. Journal of Business Ethics, 81, 143-156. http://dx.doi.org/10.1007/s10551-007-9485-2

Locke, R. M., Qin, F., \& Brause, A. (2007). Does Monitoring Improve Labor Standards? Lessons from Nike. Industrial \& Labor Relations Review, 61(1), 3-31.

Locke, R. M., \& Romis, M. (2007). Improving Work Conditions in a Global Supply Chain. MIT Management Review, 48(2), 54-61.

Lund-Thomsen, P. (2008). The Global Sourcing and Codes of Conduct Debate: Five Myths and Five Recommendations. Development and Change, 39(6), 1005-1018. http://dx.doi.org/10.1111/j.1467-7660.2008.00526.x

Lynch, R. (2009). Strategic Management. (5th ed.). Essex: Prentice Hall.

Maignan, I., Hillebrand, B., \& McAlister, D. (2002). Managing Socially-Responsible Buying: How to Integrate Non-economic Criteria into the Purchasing Process. European Management Journal, 20(6), 641-648. http://dx.doi.org/10.1016/S0263-2373(02)00115-9

Maloni, M. J., \& Brown, M. E. (2006). Corporate Social Responsibility in the Supply Chain: An Application in the Food Industry. Journal of Business Ethics, 68, 35-52. http://dx.doi.org/10.1007/s10551-006-9038-0

Mamic, I. (2005). Managing Global Supply Chain: The Sports Footwear, Apparel and Retail Sectors. Journal of Business Ethics, 59, 81-100. http://dx.doi.org/10.1007/s10551-005-3415-y

Manning, L., Baines, R. N., \& Chadd, S. A. (2006). Ethical modeling of the food supply chain. British Food Journal, 108(5), 358-370. http://dx.doi.org/10.1108/00070700610661330

Mather, C. (2004). Codes of Conduct, retailer buying practices and farm labour in South Africa's wine and deciduous fruit export chains. International Development Planning Review, 6(4), 477-493. http://dx.doi.org/10.3828/idpr.26.4.7

McWilliams, A., Siegal, D. D., \& Wright, P. M. (2006). Corporate social responsibility, strategic implications. Journal of Management Studies, 43(1), 1-18. http://dx.doi.org/10.1111/j.1467-6486.2006.00580.x 
Miles, M. P., \& Munilla, L. S. (2004). The Potential Impact of Social Accountability Certification on Marketing: A Short Note. Journal of Business Ethics, 50, 1-11. http://dx.doi.org/10.1023/B:BUSI.0000021139.94166.74

Millington, A., Eberhardt, M., \& Wilkinson, B. (2005). Gift Giving, Guanxi and Illicit Payments in Buyer-Supplier Relations in China: Analysing the Experience of UK Companies. Journal of Business Ethics, 57, 255-268. http://dx.doi.org/10.1007/s10551-004-6712-y

Ni, D. B., Li, K. W., \& Tang, X. W. (2010). Social responsibility allocations in two-echelon supply chains. Insights from wholesale price contracts. European Journal of Operational Research, 207(3), 1269-1279. http://dx.doi.org/10.1016/j.ejor.2010.06.026

Norris, G., \& O'Dwyer, B. (2004). Motivating socially responsive decision making: the operation of management controls in a socially responsive organization. The British Accounting Review, 36(2), 173-196. http://dx.doi.org/10.1016/j.bar.2003.11.004

Oehmen, J., De Nardo, M., Schonsleben, P., \& Boutellier, R. (2010). Supplier code of conduct - state of the art and customisation in the electronics industry. Production Planning and Control, 21(7), 664-679. http://dx.doi.org/10.1080/09537280903547785

Palazzo, G., \& Richter, U. (2005). CSR Business as Usual? The Case of the Tobacco Industry. Journal of Business Ethics, 61, 387-401. http://dx.doi.org/10.1007/s10551-005-7444-3

Panapanaan, V. M., Linnanen, L., Karvonen, M. M., \& Phan, V. T. (2003). Roadmapping Corporate Social Responsibility in Finnish Companies. Journal of Business Ethics, 44, 133-148. http://dx.doi.org/10.1023/A:1023391530903

Park, H. (2005). The Role of Idealism and Relativism as Dispositional Characteristics in the Socially Responsible Decision-Making Process. Journal of Business Ethics, 56, 81-98. http://dx.doi.org/10.1007/s10551-004-3239-1

Paton, D., \& Siegel, D. S. (2005). The economics of corporate social responsibility: an overview of the special issue. Structural Change and Economic Dynamics, 16(3), 309-312. http://dx.doi.org/10.1016/j.strueco.2004.04.007

Payne, D. M., \& Raiborn, C. A. (2001). Sustainable Development: The Ethics Support the Economics. Journal of Business Ethics, 32, 157-168. http://dx.doi.org/10.1023/A:1010726830191

Pedersen, E. R. (2009). The many and the few: rounding up the SMEs that manage CSR in the supply chain. Supply Chain Management: An International Journal, 14(2), 109-116. http://dx.doi.org/10.1108/13598540910941975

Pettigrew, A. M. (2006). Corporate Social responsibility in Strategy. In Craig Smith, N. and Lenssen, G. (Eds.), Mainstreaming Corporate Responsibility. Wiley.

Petrovic-Lazarevic, S. (2008). The development of corporate social responsibility in the Australian construction industry. Construction Management and Economics, 26(February), 93-101. http://dx.doi.org/10.1080/01446190701819079

Piercy, N. F. \& Lane, N. (2007). Ethical and Moral Dilemmas Associated with Strategic Relationships between Business-to-Business Buyers and Sellers. Journal of Business Ethics, 72, 87-102. http://dx.doi.org/10.1007/s10551-006-9158-6

Prieto-Carron, M. (2008). Women Workers, Industrialization, Global Supply Chains and Corporate Codes of Conduct. Journal of Business Ethics, 83, 5-17. http://dx.doi.org/10.1007/s10551-007-9650-7

Roberts, S. (2003). Supply Chain Specific? Understanding the Patchy Success. Journal of Business Ethics, 44, 159-170. http://dx.doi.org/10.1023/A:1023395631811

Razzaque, M. A., \& Hwee, T. P. (2002). Ethics and Purchasing Dilemma: A Singaporean View. Journal of Business Ethics, 35, 307-326. http://dx.doi.org/10.1023/A:1013853021571

Rimmington, M., Smith, J. C., \& Hawkins, R. (2006). Corporate social responsibility and sustainable food procurement. British Food Journal, 108(10), 824-837. http://dx.doi.org/10.1108/00070700610702082

Rode, J., Hogarth, R. M., \& Le Menestrel, M. (2008). Ethical differentiation and market behaviour: An experimental approach. Journal of Economic Behavior \& Organization, 66, 265-280. http://dx.doi.org/10.1016/j.jebo.2006.12.003

Rondinelli, D. A. \& Berry, M. A. (2000). Environmental citizenship in multinational corporations: social 
responsibility and sustainable development. European Management Journal, 18(1), 70-84. http://dx.doi.org/10.1016/S0263-2373(99)00070-5

Santoro, M. A. (2003). Beyond Codes of Conduct and Monitoring: An Organizational Integrity Approach to Global Labor Practices. Human Rights Quarterly, 25(May), 407-424. http://dx.doi.org/10.1353/hrq.2003.0022

Schwartz, K., Tapper, R., \& Font, X. (2008). A Sustainable Supply Chain Management Framework for Tour Operators. Journal of Sustainable Tourism, 16(3), 298-314.

Setthasakko, W. (2007). Determinants of corporate sustainability: Thai frozen seafood processors. British Food Journal, 109(2), 155-168. http://dx.doi.org/10.1108/00070700710725518

Seuring, S., \& Müller, M. (2008). From a literature review to a conceptual framework for sustainable supply chain management. Journal of Cleaner Production, 16, 1699-1710. http://dx.doi.org/10.1016/j.jclepro.2008.04.020

Seuring, S., Sarkis, J., Müller, M., \& Rao, P. (2008). Sustainability and supply chain management - An introduction to the special issue. Journal of Cleaner Production, 16, 1545-1551. http://dx.doi.org/10.1016/j.jclepro.2008.02.002

Svensson, G., \& Bååth, H. (2008). Supply chain management ethics: conceptual framework and illustration. Supply Chain Management: An International Journal, 13(6), 398-405. http://dx.doi.org/10.1108/13598540810905651

Tate, W. L., Ellram, L. M., \& Kirchoff, J. F. (2010). Corporate social responsibility reports: A thematic analysis related to supply chain management. Journal of Supply Chain Management, 46(1), 19-44. http://dx.doi.org/10.1111/j.1745-493X.2009.03184.x

Thompson, J., \& Martin, F. (2010). Strategic management Awareness \& Change, South-Western Cengage Learning.

Tsoi, J. (2010). Stakeholders' perception and future scenarios to improve corporate social responsibility in Hong Kong and mainland China. Journal of Business Ethics, 91(3), 391-404. http://dx.doi.org/10.1007/s10551-009-0091-3

UN (2011). [Online] Available: http://www.unglobalcompact.org/AboutTheGC/TheTenPrinciples/index.html (November 7th,2011)

Vaaland, T. I., Heide, M., \& Grønhaug, K. (2008). Corporate social responsibility: investigating theory and research in the marketing context. European Journal of Marketing, 42(9/10), 927-953. http://dx.doi.org/10.1108/03090560810891082

Vaaland, T. I., \& Heide, M. (2005). Corporate social responsiveness: exploring the dynamics of "bad episodes". European Management Journal, 23(5), 495-506. http://dx.doi.org/10.1016/j.emj.2005.09.005

Van Tulder, R., \& Kolk, A. (2001). Multinationality and corporate ethics: Codes of conduct in the sporting goods industry. Journal of International Business Studies, 32(2), 267-283. http://dx.doi.org/10.1057/palgrave.jibs.8490952

Van Weele, A. J. (2010). Purchasing and Supply Chain Management. Analysis, Strategy, Planning and Practice. Cengage Learning.

Welford, R., Meaton, J., \& Young, W. (2003). Fair trade as a strategy for international competitiveness. International Journal of Sustainable Development, 10, 1-13.

Worthington, I., Ram, M., Boyal, H., \& Shah. M. (2008). Researching the Drivers of Socially Responsible Purchasing: A Cross-National Study of Supplier Diversity Initiatives. Journal of Business Ethics, 79, 319-331. http://dx.doi.org/10.1007/s10551-007-9400-x

Yu, X. (2008). Impacts of Corporate Code of Conduct on Labor Standards: A Case Study of Reebok's Athletic Footwear Supplier Factory in China. Journal of Business Ethics, 81, 513-529. http://dx.doi.org/10.1007/s10551-007-9521-2 
Table 1. The roles of SME vs MNE as facilitator of a responsible supply chain

\begin{tabular}{|c|c|c|}
\hline Dimension & SME & MNE \\
\hline $\begin{array}{l}\text { CSR } \\
\text { expectations } \\
\text { at B2S level }\end{array}$ & $\begin{array}{l}\text { While CSR concerns all companies, there is } \\
\text { a general expectation that SMEs cannot } \\
\text { influence the supply chain as much as } \\
\text { MNEs (Pedersen, 2009; Palazzo and } \\
\text { Richter, 2005; Roberts, 2003). } \\
\text { Legal and NGO expectations include the } \\
\text { SMEs, but the level of pressure may be less } \\
\text { than on MNEs (Smith, 2009; Roberts, } \\
\text { 2003). }\end{array}$ & $\begin{array}{l}\text { While CSR concerns all companies, } \\
\text { there is a general expectation that MNEs } \\
\text { are very powerful in supply chain } \\
\text { (Pedersen, 2009; Palazzo and Richter, } \\
\text { 2005; Roberts, 2003). } \\
\text { Stakeholder and societal pressure is high } \\
\text { on MNEs. Legal and NGO demands are } \\
\text { primarily made on MNEs (Smith, 2009; } \\
\text { Roberts, 2003). }\end{array}$ \\
\hline $\begin{array}{l}\text { Conventional } \\
\text { SCM }\end{array}$ & $\begin{array}{l}\text { Limited influence on relationships and } \\
\text { limited ability to monitor suppliers' } \\
\text { compliance with code of conduct } \\
\text { (Pedersen, 2009). } \\
\text { Identification and selection of partners is } \\
\text { important to avoid irresponsible business } \\
\text { partner. However, limited resources provide } \\
\text { limited ability to achieve this (Ciliberti et } \\
\text { al., 2008a). }\end{array}$ & $\begin{array}{l}\text { The MNE has power in the supply chain, } \\
\text { and able to exercise power on suppliers } \\
\text { (Lim and Phillips, 2008; Amaeshi et al., } \\
\text { 2007). } \\
\text { As main actor in the supply chain, all } \\
\text { core activities and processes should be } \\
\text { integrated with CSR, and include smaller } \\
\text { actors in the chain (Lim and Phillips, } \\
\text { 2008; Amaeshi et al., 2007). }\end{array}$ \\
\hline $\begin{array}{l}\text { Responsible } \\
\text { SCM }\end{array}$ & $\begin{array}{l}\text { CSR strategies tend to be more } \\
\text { internally-oriented. } \\
\text { Low power and influence on the chain } \\
\text { could make it difficult to put through own } \\
\text { strategies and implement own tools and } \\
\text { activities (Lim and Phillips, 2008, Amaeshi } \\
\text { et al., 2007). } \\
\text { SMEs should succeed in implementing } \\
\text { CSR in the supply chain by placing } \\
\text { emphases on own values as responsible } \\
\text { business partners } \\
\text { (Ciliberti et al., 2008a). }\end{array}$ & $\begin{array}{l}\text { Values, strategies and tactics should } \\
\text { include internal, B2B and B2S } \\
\text { ambitions. Power and size gives the } \\
\text { MNE influence on stakeholder dialogue } \\
\text { and ability to bridge expectancy gaps } \\
\text { between the chain and society (Lim and } \\
\text { Phillips, 2008, Amaeshi et al., 2007) } \\
\text { All dimensions (i.e. values, strategies } \\
\text { and tactics) are important to sustain } \\
\text { responsibility. Power and influence } \\
\text { should be used systematically to reduce } \\
\text { reputational risk and improve } \\
\text { responsibility. }\end{array}$ \\
\hline
\end{tabular}

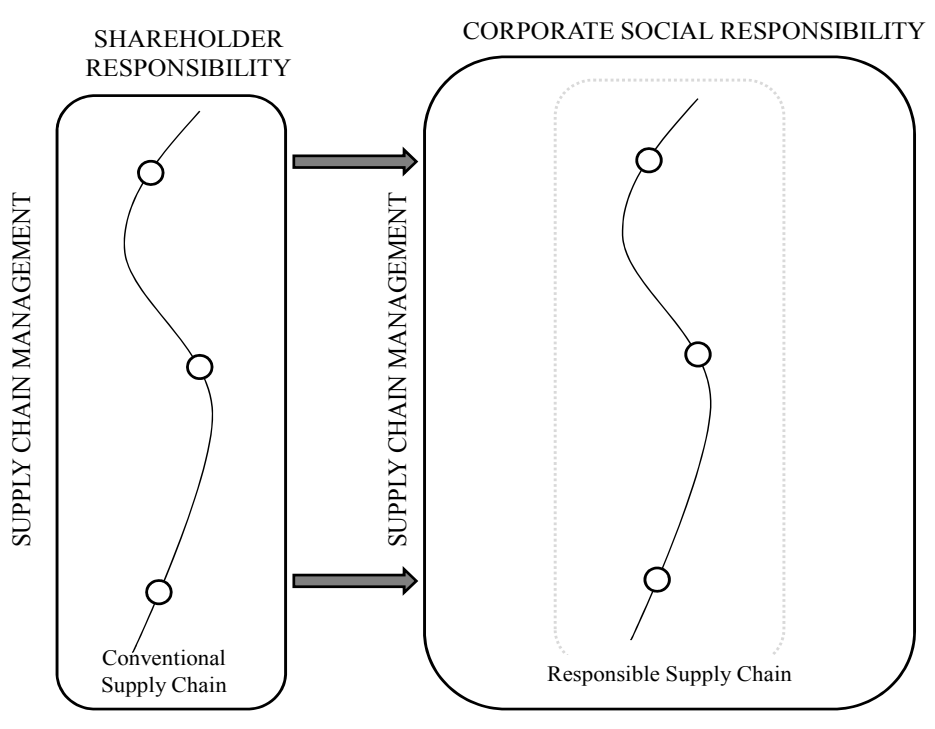

Figure 1. The aim of the paper 


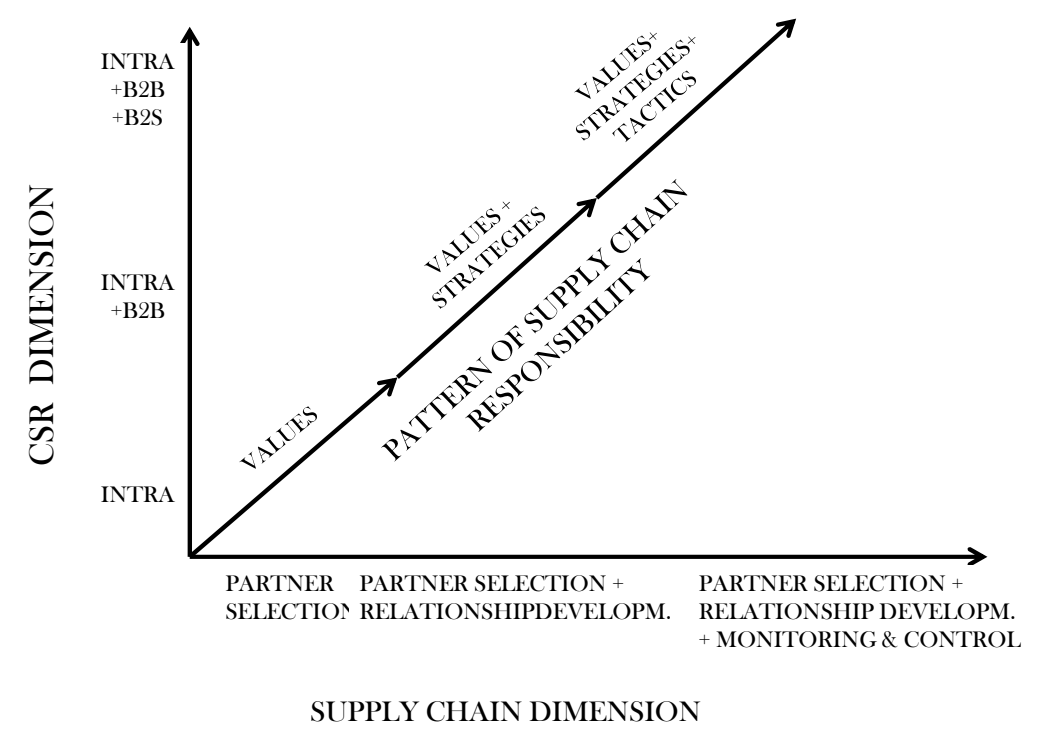

Figure 2. Supply Chain Responsibility

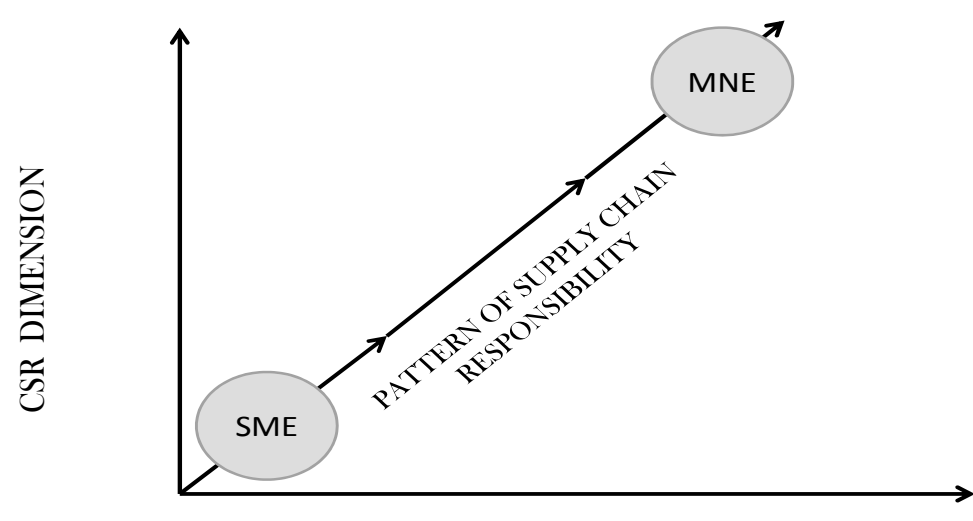

SUPPLY CHAIN DIMENSION

Figure 3. The individual company's responsibility in a responsible supply chain 


\section{Appendices}

Appendix 1. List of journals

\begin{tabular}{|c|c|c|c|}
\hline Journal & Abbrev. & Journal & Abbrev. \\
\hline Antipode & $\mathrm{A}^{*}$ & $\mathrm{~J}$ of Business Ethics & JBE \\
\hline British Food Journal & BFJ & $\mathrm{J}$ of Business Research & JBR \\
\hline $\begin{array}{l}\text { Construction Management \& } \\
\text { Economics }\end{array}$ & CM\&E & $\mathrm{J}$ of Contemporary Asia & JCA \\
\hline Development and Change & $\mathrm{D} \& \mathrm{C}$ & $\mathrm{J}$ of Cleaner Production & $\mathrm{JCP}$ \\
\hline European J of Operational Research & EJOR & $\mathrm{J}$ of Economic Behavior \& Organiz. & JEBO \\
\hline European Management Journal & EMJ & $\begin{array}{l}\mathrm{J} \text { of Environmental Planning and } \\
\text { Management }\end{array}$ & JEPM \\
\hline $\begin{array}{l}\text { Entrepreneurship and Regional } \\
\text { Development }\end{array}$ & ERD & $\mathrm{J}$ of International Business Studies & JIBS \\
\hline Environment and Planning & E\&P & J of Industrial Relations & JIR \\
\hline Geographical Research & GR & $\mathrm{J}$ of Marketing Management & JMM \\
\hline Human Rights Quarterly & HRQ & $\mathrm{J}$ of Operations Management & JOM \\
\hline I Development Planning Review & IDPR & J of Supply Chain Management & JSCM \\
\hline IJ of Logistics-Research \& Applications & IJL & Long Range Planning & LRP \\
\hline I J Production Economics & IJPE & Production Planning \& Control & PPC \\
\hline $\begin{array}{l}\text { I J of Retail \& Distribution } \\
\text { Management }\end{array}$ & IJRDM & Supply Chain Management: An I J & $\mathrm{SCM}$ \\
\hline I J of Production Research & IJPR & Sustainable Development & SD \\
\hline Industrial \& Labor Relations Review & ILRR & $\begin{array}{l}\text { I J of Sustainable Development and } \\
\text { World Ecology }\end{array}$ & SDWE \\
\hline Industrial Marketing and Management & IMM & MIT Sloan Management Review & SMR \\
\hline $\mathrm{J}$ of the Academy of Marketing Science & JAMS & & \\
\hline
\end{tabular}

* Abbreviation of journal title in the columns. 
Appendix 2a. Conceptual/Theoretical articles

\begin{tabular}{|c|c|c|}
\hline Author & Article name & Journal \\
\hline $\begin{array}{l}\text { Amaeshi, Osuji \& Nnodim } \\
(2007)\end{array}$ & $\begin{array}{l}\text { Corporate Social Responsibility in Supply Chains of Global } \\
\text { Brands: A Boundaryless Responsibility? Clarifications, } \\
\text { Exceptions and Implications. }\end{array}$ & JBE \\
\hline Barrientos (2008) & $\begin{array}{l}\text { Contract labor: The "Achilles Heel" of Corporate Codes in } \\
\text { Commercial Value Chains }\end{array}$ & $\mathrm{D \& C}$ \\
\hline Blowfield (2000). & Ethical sourcing: a contribution to sustainability or a diversion. & $\mathrm{SD}$ \\
\hline $\begin{array}{l}\text { Boyd, Spekman, Kamauff \& } \\
\text { Werhane (2006) }\end{array}$ & $\begin{array}{l}\text { Corporate Social responsibility in Global Supply Chains: A } \\
\text { Procedural Justice Perspective }\end{array}$ & LRP \\
\hline Butter \& Linse (2008) & Rethinking Procurement in the Era of Globalization & SMR \\
\hline Craig Smith (2009) & $\begin{array}{l}\text { Bounded goodness: marketing implications of Drücker on } \\
\text { corporate responsibility }\end{array}$ & JAMS \\
\hline Cramer (2008) & $\begin{array}{l}\text { Organizing corporate social responsibility in international } \\
\text { product chains }\end{array}$ & JCP \\
\hline Cruz (2008) & $\begin{array}{l}\text { Dynamics of supply chain } \begin{array}{c}\text { networks with corporate social } \\
\text { responsibility } \\
\text { through }\end{array} \text { integrated } \\
\text { decision-making }\end{array}$ & EJOR \\
\hline Cruz \& Matsypura (2009) & $\begin{array}{l}\text { Supply chain networks with corporate social responsibility } \\
\text { through integrated environmental decision-making }\end{array}$ & IJPR \\
\hline Cruz \& Wakolbinger (2008) & $\begin{array}{l}\text { Multi-period effects of corporate social responsibility on supply } \\
\text { chain networks, transaction costs, emissions, and risk }\end{array}$ & IJPE \\
\hline Drake \& Schlachter (2008) & A Virtue-Ethics Analysis of Supply Chain Collaboration & JBE \\
\hline Emiliani (2005) & $\begin{array}{l}\text { Regulating B2B online reverse auctions through voluntary } \\
\text { codes of conduct }\end{array}$ & IMM \\
\hline Fisher (2007) & Business marketing and the ethics of gift giving & IMM \\
\hline Hsueh \& Chang (2008) & $\begin{array}{l}\text { Equilibrium analysis and corporate social responsibility for } \\
\text { supply chain integration }\end{array}$ & EJOR \\
\hline $\begin{array}{l}\text { Hutchinson \& Sutherland } \\
(2008)\end{array}$ & $\begin{array}{l}\text { An exploration of measures of social sustainability and their } \\
\text { application to supply chain decisions }\end{array}$ & $\mathrm{JCP}$ \\
\hline Lund-Thomsen (2008) & $\begin{array}{l}\text { The Global Sourcing and Codes of Conduct Debate: Five Myths } \\
\text { and Five Recommendations }\end{array}$ & $\mathrm{D} \& \mathrm{C}$ \\
\hline $\begin{array}{l}\text { Maignan, Hillebrand \& } \\
\text { McAlister (2002) }\end{array}$ & $\begin{array}{l}\text { Managing Socially-Responsible Buying: How to Integrate } \\
\text { Non-economic Criteria into the Purchasing Process. }\end{array}$ & EMJ \\
\hline Maloni \& Brown (2006) & $\begin{array}{l}\text { Corporate Social responsibility in the Supply Chain: An } \\
\text { Application in the Food Industry }\end{array}$ & JBE \\
\hline $\begin{array}{l}\text { Manning, Baines \& Chadd } \\
(2006)\end{array}$ & Ethical modeling of the food supply chain & BFJ \\
\hline Miles \& Munilla (2004) & $\begin{array}{l}\text { The Potential Impact of Social Accountability Certification on } \\
\text { Marketing: A Short Note }\end{array}$ & JBE \\
\hline Ni, Li, \& Tang (2010) & $\begin{array}{l}\text { Social responsibility allocations in two-echelon supply chains. } \\
\text { Insights from wholesale price contracts }\end{array}$ & EJOR \\
\hline Piercy \& Lane (2006) & $\begin{array}{l}\text { Ethical and Moral Dilemmas Associated with Strategic } \\
\text { Relationships between Business-to-Business Buyers and Sellers }\end{array}$ & JBE \\
\hline Prieto-Carrón (2008) & $\begin{array}{l}\text { Women Workers, Industrialization, Global Supply Chains and } \\
\text { Corporate Codes of Conduct }\end{array}$ & JBE \\
\hline $\begin{array}{l}\text { Schwartz, Tapper \& Font } \\
(2008)\end{array}$ & $\begin{array}{l}\text { A sustainable supply chain management framework for tour } \\
\text { operators }\end{array}$ & JST \\
\hline $\begin{array}{l}\text { Seuring, Sarkis, Müller \& } \\
\text { Rao (2008) }\end{array}$ & $\begin{array}{l}\text { Sustainability and supply chain management - An introduction } \\
\text { to the special issue }\end{array}$ & JCP \\
\hline $\begin{array}{l}\text { Welford, Meaton \& Young } \\
\text { (2003) }\end{array}$ & Fair trade as a strategy for international competitiveness & SDWE \\
\hline
\end{tabular}


Appendix 2b. Empirical articles

\begin{tabular}{|c|c|c|}
\hline Author & Article name & Journal \\
\hline Aaronson (2005) & $\begin{array}{l}\text { "Minding Our Business": What the United States Government has } \\
\text { done and can do to Ensure that U.S. Multinationals Act Responsibly } \\
\text { in Foreign markets }\end{array}$ & JBE \\
\hline $\begin{array}{l}\text { Baker, Hunt \& Andrews } \\
(2006)\end{array}$ & $\begin{array}{l}\text { Promoting ethical behavior and organizational citizenship } \\
\text { behaviors: The influence of corporate ethical values }\end{array}$ & JBR \\
\hline Bendixen \& Abratt (2007) & $\begin{array}{l}\text { Corporate Identity, Ethics and Reputation in Supplier-Buyer } \\
\text { Relationship }\end{array}$ & JBE \\
\hline $\begin{array}{l}\text { Besser, Miller \& Perkins } \\
(2006)\end{array}$ & $\begin{array}{l}\text { For the greater good: business networks and business social } \\
\text { responsibility to communities }\end{array}$ & ERD \\
\hline Carter (2000) & $\begin{array}{l}\text { Ethical issues in international buyer-seller relationships: a dyadic } \\
\text { examination }\end{array}$ & $\mathrm{JOM}$ \\
\hline Carter \& Jennings (2002) & Social responsibility and supply chain relationships & TRPE \\
\hline Choi \& Jung (2007) & $\begin{array}{l}\text { Ethical Commitment, Financial Performance, and Valuation: An } \\
\text { Empirical Investigation of Korean Companies }\end{array}$ & JBE \\
\hline $\begin{array}{l}\text { Christmann \& Taylor } \\
(2006)\end{array}$ & $\begin{array}{l}\text { Firm self regulation through international certifiable standards: } \\
\text { determinants of symbolic versus substantive implementation }\end{array}$ & JIBS \\
\hline $\begin{array}{l}\text { Ciliberti, Pontrandolfo \& } \\
\text { Scozzi (2008a) }\end{array}$ & $\begin{array}{l}\text { Investigating corporate social responsibility in supply chain: a SME } \\
\text { perspective }\end{array}$ & JCP \\
\hline $\begin{array}{l}\text { Ciliberti, Pontrandolfo \& } \\
\text { Scozzi (2008b) }\end{array}$ & $\begin{array}{l}\text { Logistics social responsibility: Standard adoption and practices in } \\
\text { Italian companies }\end{array}$ & IJPE \\
\hline Cole, Sirgy \& Bird (2000) & $\begin{array}{l}\text { How do managers make teleological evaluations in ethical } \\
\text { dilemmas? Testing part of and extending the Hunt-Vitell model }\end{array}$ & JBE \\
\hline $\begin{array}{l}\text { Dubbink \& vd Putten } \\
(2007)\end{array}$ & Is Competition Law an Impediment to CSR? & JBE \\
\hline Faisal (2010). & $\begin{array}{l}\text { Analysing the barriers to corporate social responsibility in supply } \\
\text { chains: an interpretive structural modeling approach. }\end{array}$ & IJL \\
\hline Egels-Zandén (2007) & $\begin{array}{l}\text { Suppliers' Compliance with MNC Codes of Conduct: Behind the } \\
\text { Scenes at Chinese Toy Suppliers. }\end{array}$ & JBE \\
\hline $\begin{array}{l}\text { Fearne, Duffy \& } \\
\text { Hornibrook (2005) }\end{array}$ & $\begin{array}{l}\text { Justice in UK supermarket buyer-supplier relationships: an } \\
\text { empirical analysis }\end{array}$ & IJRDM \\
\hline $\begin{array}{l}\text { Ford, LaTour \& } \\
\text { Henthorne }(2000)\end{array}$ & $\begin{array}{l}\text { Cognitive Moral Development and Japanese } \text { Procurement } \\
\text { Executives. Implications for Industrial Marketers }\end{array}$ & IMM \\
\hline $\begin{array}{l}\text { Giampetro \& Emiliani } \\
(2007)\end{array}$ & Coercion and reverse auctions & SCM \\
\hline $\begin{array}{l}\text { Gonzalez-Padron, Hult \& } \\
\text { Calantrone (2008) }\end{array}$ & $\begin{array}{l}\text { Exploiting innovative opportunities in global purchasing: An } \\
\text { assessment of ethical climate and relationship performance }\end{array}$ & IMM \\
\hline Hale \& Opondo (2005) & $\begin{array}{l}\text { Humanizing the cut flower chain: Confronting the realities of flower } \\
\text { production for workers in Kenya }\end{array}$ & A \\
\hline Hughes (2005) & $\begin{array}{l}\text { Corporate strategy and the management of ethical trade: the case of } \\
\text { UK food and clothing retailers }\end{array}$ & E\&P \\
\hline Jiang (2009) & $\begin{array}{l}\text { Implementing Supplier Codes of Conduct in Global Supply Chains: } \\
\text { process Explanations from Theoretic and Empirical Perspectives }\end{array}$ & JBE \\
\hline $\begin{array}{l}\text { Jones, Comfort, Hillier \& } \\
\text { Eastwood (2005) }\end{array}$ & $\begin{array}{l}\text { Corporate social responsibility: a case study of the UK's leading } \\
\text { food retailers }\end{array}$ & BFJ \\
\hline $\begin{array}{l}\text { Keating, Quazi, Kritz \& } \\
\text { Coltman (2008) }\end{array}$ & $\begin{array}{l}\text { In pursuit of sustainable supply chain: insights from Westpac } \\
\text { Banking Corporation }\end{array}$ & SCM \\
\hline Lahdesmaki (2005) & $\begin{array}{l}\text { When Ethics Matters - Interpreting the Ethical Discourse of Small } \\
\text { Nature-based Entrepreneurs }\end{array}$ & JBE \\
\hline Laudal (2010) & $\begin{array}{l}\text { An attempt to determine the CSR potential of the international } \\
\text { clothing business. }\end{array}$ & JBE \\
\hline Lawrence (2007) & $\begin{array}{l}\text { Corporate Social responsibility, Supply-chains and Saami Claims: } \\
\text { Tracing the Political in the Finnish Forestry Industry }\end{array}$ & GR \\
\hline Lillywhite (2007) & $\begin{array}{l}\text { Ethical purchasing and worker's rights in China: The case of the } \\
\text { Brotherhood of St.Laurence. }\end{array}$ & JIR \\
\hline
\end{tabular}




\begin{tabular}{|c|c|c|}
\hline Author & Article name & Journal \\
\hline Lim \& Phillips (2008) & $\begin{array}{l}\text { Embedding CSR values: The Global Footwear Industry's Evolving } \\
\text { Governance Structure. }\end{array}$ & JBE \\
\hline Locke \& Romis (2007) & Improving work conditions in global supply chain & SMR \\
\hline $\begin{array}{l}\text { Locke, Qin \& Brause } \\
(2007)\end{array}$ & Does monitoring improve labor standards? Lessons from Nike & ILRR \\
\hline $\begin{array}{l}\text { Maignan \& McAlister } \\
(2003)\end{array}$ & $\begin{array}{l}\text { Social responsible organizational buying; how can stakeholder } \\
\text { dictate purchasing policies? }\end{array}$ & JMM \\
\hline Mamic (2005) & $\begin{array}{l}\text { Managing Global Supply Chain: The Sportswear. Apparel and } \\
\text { Retail Sectors }\end{array}$ & JBE \\
\hline Mather (2004) & $\begin{array}{l}\text { Codes of conduct/retainer buying practices and farm labor in South } \\
\text { Africa's wine and deciduous fruit export chains }\end{array}$ & IDPR \\
\hline $\begin{array}{l}\text { Millington, Eberhardt \& } \\
\text { Wilkinson (2005) }\end{array}$ & $\begin{array}{l}\text { Gift Giving, Guanxi and Illicit Payment in Buyer-Supplier Relations } \\
\text { in China: Analyzing the Experience of UK Companies }\end{array}$ & JBE \\
\hline Nadvi (2008) & $\begin{array}{l}\text { Global standards, global governance and the organization of global } \\
\text { value chains }\end{array}$ & JEG \\
\hline $\begin{array}{l}\text { Oehmen, De Nardo, } \\
\text { Schonsleben \& Boutellier } \\
(2010)\end{array}$ & $\begin{array}{l}\text { Supplier code of conduct - state of the art and customization in the } \\
\text { electronics industry. }\end{array}$ & PPC \\
\hline Palazzo \& Richter (2005) & CSR Business as Usual? The case of Tobacco Industry & JBE \\
\hline $\begin{array}{l}\text { Panapanaan, Linnanen, } \\
\text { Karvonen \& Phan (2003) }\end{array}$ & $\begin{array}{lllll}\begin{array}{l}\text { Roadmapping } \\
\text { Companies }\end{array} & \text { Corporate } & \text { Social } & \text { Responsibility in Finnish } \\
\end{array}$ & JBE \\
\hline Pangsapa \& Smith (2008) & $\begin{array}{l}\text { Political economy of Southeast Asian borderlands: Migration, } \\
\text { environment, and developing country firms }\end{array}$ & JCA \\
\hline Park (2005) & $\begin{array}{l}\text { The Role of Idealism and Relativism as Dispositional } \\
\text { Characteristics in the Socially } \\
\text { Process }\end{array}$ & JBE \\
\hline Petrovic-Lazarevic (2008) & $\begin{array}{l}\text { The development of corporate social responsibility in the Australian } \\
\text { construction industry. }\end{array}$ & $\mathrm{CM} \& \mathrm{E}$ \\
\hline Razzaque \& Hwee (2002) & Ethics and Purchasing Dilemma: A Singaporean View & JBE \\
\hline $\begin{array}{l}\text { Rimmington, Smith \& } \\
\text { Hawkins (2006) }\end{array}$ & Corporate social responsibility and sustainable food procurement & $\mathrm{BFJ}$ \\
\hline $\begin{array}{l}\text { Roberts, Lawson \& } \\
\text { Nicholls (2006) }\end{array}$ & $\begin{array}{l}\text { Generating Regional-Scale Improvements in SME Corporate } \\
\text { Responsibility performance: lessons from Responsibility Northwest }\end{array}$ & JBE \\
\hline $\begin{array}{l}\text { Rode, Hogarth \& Le } \\
\text { Menestrel (2008) }\end{array}$ & $\begin{array}{l}\text { Ethical differentiation and market behavior: An experimental } \\
\text { approach }\end{array}$ & JEBO \\
\hline Santoro (2003) & $\begin{array}{l}\text { Beyond codes of conduct and monitoring: An organizational } \\
\text { integrity approach to global labor practices. }\end{array}$ & HRQ \\
\hline Setthasakko (2007) & $\begin{array}{l}\text { Determinants of corporate sustainability: Thai frozen seafood } \\
\text { processors }\end{array}$ & $\mathrm{BFJ}$ \\
\hline $\begin{array}{l}\text { Studer, Tsang, Welford \& } \\
\text { Hills (2008) }\end{array}$ & $\begin{array}{l}\begin{array}{l}\text { SMEs and voluntary environmental initiatives: as study of } \\
\text { stakeholders' perspectives in Hong Kong }\end{array} \\
\end{array}$ & JEPM \\
\hline Svensson \& Baath (2008) & $\begin{array}{l}\text { Supply chain management ethics: conceptual framework and } \\
\text { illustration }\end{array}$ & $\mathrm{SCM}$ \\
\hline $\begin{array}{l}\text { Tate, Ellram \& Kirchoff } \\
\text { (2010). }\end{array}$ & $\begin{array}{l}\text { Corporate social responsibility reports: A thematic analysis related } \\
\text { to supply chain management. }\end{array}$ & JSCM \\
\hline Tsoi (2010). & $\begin{array}{l}\text { Stakeholders' perception and future scenarios to improve corporate } \\
\text { social responsibility in Hong Kong and mainland China }\end{array}$ & JBE \\
\hline Tulder and Kolk (2001) & $\begin{array}{l}\text { Multinationality and corporate ethics: Codes of conduct in the } \\
\text { sporting industry }\end{array}$ & JIBS \\
\hline Vachon \& Mao (2008) & $\begin{array}{l}\text { Linking supply chain strength to sustainable development: a } \\
\text { country-level analysis }\end{array}$ & $\mathrm{JCP}$ \\
\hline $\begin{array}{l}\text { Worthington, Ram, Boyal } \\
\text { \& Shah (2007) }\end{array}$ & $\begin{array}{l}\text { Researching the Drivers of Socially Responsible Purchasing: A } \\
\text { Cross-National Study of Supplier Diversity Initiatives. }\end{array}$ & JBE \\
\hline Yu (2008) & $\begin{array}{l}\text { Impacts of Corporate Code of Conduct on Labor Standards: A Case } \\
\text { Study of Reebok's Athletic Footwear Supplier factory in China }\end{array}$ & JBE \\
\hline
\end{tabular}

